\title{
DOCUMENTS
}

\section{CONCEPT OF NATIONAL SECURITY OF MONGOLIA}

\section{GENERAL PROVISIONS}

1. The Constitution of Mongolia expresses the integrated interests of the people, all groups and strata of Mongolian society.

2. The national security of Mongolia (hereinafter referred to as "national security") represents the status when favorable external and internal conditions are secured to ensure vital national interests of Mongolia. The ideological basis of the policy ensuring national security is national patriotism.

3. The vital national interests of Mongolia consist in the existence of the Mongolian people and their civilization, in the country's independence, sovereignty, territorial integrity, inviolability of State frontiers, relative economic independence, sustainable ecological development and national unity. The vital national interests of Mongolia constitute the object of special care and protection on the part of the State and the people.

4. The insurance of national security implies State policy aimed at creating all-round guarantees of protecting and strengthening of Mongolia's vital national interests, actions taken by the Slate, its agencies and functionaries to that effect as well as measures implemented by its citizens. Those measures shall be of both preventive and creative nature. Mongolia shall strive to develop its international competitiveness in the economic, cultural, scientific-technological and educational fields.

\section{One. Structure of National Security}

5. The national security shall consist of the following main components:

1. Security of the existence of Mongolia

2. Security of the social order and state system

3. Security of citizens' rights and freedoms

4. Economic security

5. Scientific and technological security

6. Security of information

7. Security of Mongolian civilization

8. Security of the population and its gene pool

9. Ecological security 


\section{Two. Factors Affecting National Secirity}

6. Factors affecting the national security are divided into internal and external by their origins, and into immediate, temporary, long-term and permanent by their duration. The vital national interests of Mongolia are interests of a permanent nature.

7. The factors that may have a negative impact on national security are divided into objective and subjective by their character, and into real and possible by the probability of danger they might cause. The policy of ensuring and strengthening the national security aims at identifying and eliminating any threats at the "probable" stage of its occurrence, as well as at reducing or preventing objective threats by the timely elimination of subjective ones.

8. External factors affecting security:

The national security of Mongolia constitutes a part of the international security and as such is directly dependent on the latter. In terms of political spatial security, it is divided into global, regional and sub regional.

9. Internal factors affecting national security:

In terms of internal spatial dimension, national security shall be of national, regional, aimag, the capital, soum levels.

\section{Three. Ways and Means of Ensuring National Security, Security Guarantees}

10. National security is ensured by social, political, organizational, economic, diplomatic, military, intelligence and legal means, unilaterally or through the development of international cooperation.

11. The main means of ensuring national security consists of taking measures designed to forecast and forestall trends and the development of events on the basis of reliable information and through its evaluation and assessment.

12. The main guarantors of national security are the people of Mongolia and the Mongolian State.

13. International guarantees of national security consist of political, legal, and moral-psychological components. They are secured and strengthened through the combination of unilateral, bilateral and multilateral measures. Military-political security can be ensured through a collective security system by joint efforts or participation in such a system.

\section{Four. System of Ensuring National Security}

14. The duties to ensure national security are incumbent on the State Great Hural, the President of Mongolia, the National Security Council headed by the 
President, the Government, the central and focal law enforcement and State administrative agencies.

15. The legislative, executive, judicial and local self-governing bodies are obligated to implement, within their compe-tence, the tenets of this Concept, strengthened by the Constitu-tion, legislation and other relevant legal acts.

16. Political and public organizations, as well as citizens shall strictly observe the legislation on ensuring national security and the present Concept, and shall actively participate in the realization thereof.

17. The National Security Council is charged with the coordination of the strategies and tactics of the implementation of the present Concept with the due regard to existing circumstances. It shall monitor the state of safeguarding national security, and an-nually inform the State Great Hural thereon.

18. The organizations concerned shall provide for funds needed to implement this Concept in their budgets. In cases of special measures, expenses shall be covered by the State budget.

\section{Five. Information Database of National Security}

19. Every kind of information to coordinate and implement the State policy of ensuring national security shall be obtained from relevant authorities, citizens, and from foreign sources. The information database shall be set up under the National Security Council.

\section{SECURITY OF THE EXISTENCE OF MONGOLIA}

20. The security of the existence of Mongolia means the insurance of its independence, sovereignty, territorial integrity, and inviolability of state frontiers of Mongolia.

21. External factors which may adversely affect the security of the existence of Mongolia:

1. Armed aggression or threat of armed aggression against Mongolia from any State or force;

2. Policies designed to forcibly abolish the State independence of Mongolia or to disrupt the national unity of the people;

3. Impeding or pressuring the sovereign relations of Mon-golia with other States developed on the basis of international law;

4. Organization of terrorist and subversive activities, espionage against Mongolia and its people, as well as the abetting and conspiring in such acts;

5. Imposition by any State of its own interests and policies on Mongolia or attempts to resolve disputes by force; 
6. Imposition of political, military, economic and ideological control over Mongolia;

7. Emergence of global, regional and sub regional crises and conflicts which may affect Mongolia, or may draw it into war;

8. Destabilization of the Mongolian economy, attempts at or organizing coup detach or using Mongolia as a bridgehead for policies and activities directed against other States;

9. Changing of state frontiers, illegal border crossing and border violations;

10. Disputes and conflicts between neighboring states, And being affected by their internal contradictions and crises;

11. Massive inflows of migrants from a neighboring State;

12. Occurrence of natural and ecological calamities, out-break or spread of acutely infectious human or animal diseases.

22. Internal factors which may adversely affect the national security of Mongolia:

1. Breakdown of statehood, or designs and/or attempts at turning Mongolia into a satellite State;

2. Political, economic and military acts aimed at disrupting national unity and/or undermining the independence of Mongolia;

3. Emergence of conditions leading to acute religious, ethnic or local disputes and confrontations;

4. Organization of subversive and/or espionage activities aimed at weakening the potential of Mongolia;

5. Division within the armed forces and other military entities, loss of their defense capability or military-patriotic conscience, or confrontation between the military and civilian population or armed insurgency and conflicts.

23. Ways and means to ensure the security of the existence of Mongolia:

Mongolia shall:

One. 1. Uphold universally accepted principles of contemporary international law in relations with any State and make others observe them as well;

2. Support the activities of the United Nations Organization and other international institutions aimed at strengthening world peace and security, and closely cooperate with them to that end

3. Establish and protect bilaterally and multilaterally the legal foundations for the unilateral or collective protection of the country from aggression in conformity with Article 51 of the UN Charter; 
4. Promote the policy of maintaining strategic stability and establishing a reliable system of strengthening the peace and security in Asia and the Pacific, particularly in Northeast Asia and Central Asia;

5. Strictly observe the policy of not allowing the use of the country's territory against other States. Ensure the nuclear-Weapons-free status of Mongolia at the international level and make it an important element of strengthening the country's se-curity by political means. Pursue the policy of turning Central Asia into a nuclear-weapons-free zone;

6. Ensure timely and sound reactions to acts capable of affecting or contradicting the vital national interests of Mongolia or damaging its prestige and, if necessary, duly reflect them in the politics and activities of the government;

7. Promote an atmosphere conducive to understanding and supporting Mongolia in other countries, particularly in neighbor-ing and influential countries through the wide use of the policy of "people's diplomacy", an important channel of foreign relations;

8. Enforce legal acts that determine the overall number of foreigners and stateless persons that may reside in Mongolia and regulate their movement within the country, and monitor their compliance Establish a mechanism of control to prevent illegal residence or stay in Mongolia.

Two. 1. Cooperate with other countries and relevant international organizations in the military field, and in pursuit of the policy of safeguarding itself against possible aggression and seeking collective defense, shall follow the policy of making use of the armed forces of neighboring or of third States or the United Nations and/or other integrated international armed forces;

2. Have national armed forces, other troops capable of safeguarding the country's independence, territorial integrity and inviolability of frontiers;

3. Implement defense objectives on the basis of the universal defense system in accordance with its own military doctrine. In case of having to defend against an armed encroach-ment or aggression solely by its own forces, a selfdefense war shall be waged through the mobilization of all internal forces and means while also making wide use of external factors;

4. Participate to the greatest extent possible in international efforts and cooperation designed to strengthen trust in the military field and establish a mechanism for ensuring regional security.

\section{SECURITY OF SOCIAL ORDER AND STATE SYSTEM}

24. Security of the social order and State system means the insurance of the state and socio-economic structure, fundamental principles of State activi- 
ties, as well as human rights and freedoms as provided for in the Constitution of Mongolia.

25. External factors which may adversely affect the sectritzy of the social order and state system:

1. Policies aimed at the destruction of the State, and social economic structure of Mongolia;

2. Sowing discord among nationalities, different social groups and national leadership in order to disrupt the integrity of the state system, or disrupting the national unity of the people or an attempt to do so;

3. Divulging state secrets, including military and technological ones;

4. Espionage activities by foreign intelligence services and their accomplices.

26. Internal factors which may adversely affect the securityof the social order and state system:

1. Impair the sovereignty of Mongolia provided for by the Constitution;

2. IIIegal seizure of state power or an attempt to do so;

3. Breach of the equality of forms of property and violation of the right to own property;

4. Breach of principles of non-interference by the state agencies in religious affairs and by religious entities in state affairs;

5. Breach of the principle of separation of State powers of Mongolia;

6. Emergence of different splinter groups due to difference of views, of ethnic origin, religion, place of origin, contradictions within the national leadership on issues of national security;

7. Weakening of the country's defense potential and the ties between the people and the military;

8. Weakening of the respect for law and order in society, slackening of discipline and responsibility that lead to public disorders, weakening of State governance, accountability and vigilance, disclosure of state secrets,

9. Aggravation of corrupt practices and spread of organ-ized crime;

10. Exhaustion of strategic and other national resources, outbreak of famine and natural calamities, spread of plagues lead-ing to a large number of human deaths.

27. Ways and means to ensure the security of the social order and state system

Mongolia shall:

One. 1. Enact legislation in compliance with the spirit, prin-ciples and provisions of the Constitution of Mongolia, and ensure strict observance thereof; 
2. establish a political mechanism for the coordination of activities of political parties and movements;

3. provide conditions needed for protecting the top national leaders from influences contrary to the national interest, and take preventive and safeguarding measures;

4. make government activities transparent to the public except for cases prohibited by law for national security reasons.

Two. 1. In foreign relations, exercise political realism and consistently principled approach, according top priority to the vital interests and other national considerations, and seek to secure many partners in international relations. Promote a non-aligned policy so long as it does not threaten the country's vital interests. Whenever Mongolia's interests conflict with those of other coun-tries, a flexible approach shall be sought, bearing in mind the vital national interests of Mongolia;

2. Accord top priority to the question of relations with the two neighboring countries and adhere to the principle of a balanced relationship with them. Maintaining a balanced relationship does not mean keeping equidistance between them or taking identical positions on all issues, but this policy does mean strengthening trust and developing all-round goodneighbourty relations and mutually beneficial cooperation with both of them. In relations with these countries, due account shall be taken of their policies in regard to the national interests of Mongolia, above all its vital interests. A policy of non-involvement and neutrality shall be pursued in relation to the disputes be-tween the two neighbors unless the disputes affect the vital na-tional interests of Mongolia;

3. Pursue an open foreign policy. Promote the policy of consultation with influential countries on issues of strengthening world peace and security, of developing international cooperation, of enhancing the country's strategic significance and foster-ing strategic interests of major powers in Mongolia,

4. In its relations with other developing and landlocked countries, pursue the line of jointly defending and promoting the shared interests on the international arena.

\section{IY. SECURITY OF CITIZENS' RIGHTS AND FREEDOMS}

28 . The security of the citizens' rights and freedoms means the situation when conditions are ensured for individuals to fully devote their physical and intellectual potential to their own benefit to the interests of the country and the people, and for Mongolia to carry out its international obligations with respect 
to human rights.

29. External factors which may adversely affect the ensuring of the security of the citizens rights and freedoms:

1. Violations of constitutionally provided and guaranteed democracy, justice, equality and the citizens' rights and freedoms as a result of provocative actions and pressures by other States

2. Breach of the unity among the population and between citizens by making use of ethnic and religious distinctions, as well as differences of opinion;

3. Restrictions of the rights, freedoms and equal status of Mongolian citizens traveling abroad on business or private trips, or residing there permanently or temporarily;

4. Entrapping of Mongolian citizens by foreign agencies and services through promises, incitement and brainwashing and using them to the detriment of Mongolia's interests;

5. Emergence of dual citizenship which would result in the loss of guarantees to ensure the citizens' rights on the part of the State.

30. Internal factors which may adversely affect the ensuring of the security of the citizens' rights and freedoms:

1. Grave violations of human rights provided for by the Consituation and other laws of Mongolia, and by international treatiesand conventions to which Mongolia is a party;

2. Lack or loss of real political, economic, social and other guarantees capable of ensuring the citizens' rights and freedom's provided for by the Constitution and other legislative acts of Mongolia;

3. Loss of citizen's sense of patriotism due to hard social and economic conditions.

31. Ways and means to ensure the security of the citizens'

Rights and freedoms Mongolia shall:

1. guarantee the specific rights and freedoms of citizens provided for by the Constitution of Mongolia through the enactment of relevant legislation;

2. besides acceding to multilateral treaties and conven-tions protecting human rights and freedoms, conclude bilateral treaties and agreements ensuring the interests of this country's Citizens;

3. set up a mechanism for providing Mongolian citizens traveling abroad with the needed information on their rights and obligations, on legal means of self-protection, as well as enhance the role and responsibility of the diplomatic missions of Mongolia abroad in the protection of the rights of citizens; 
4. identify and determine the root causes of political repression, rehabilitate the victims of repression and create political and legal guarantees to prevent the recurrence of such tragedies;

5. support the activities of the non-governmental organizations aimed at protecting human rights and freedoms;

6. have the option to introduce appropriate restrictions on human rights and freedoms in accordance with the law whenever the population and the gene pool of the nation are endangered due to the outbreak of acutely infectious diseases and disparities in the age and sex ratios of the population;

7. enact legislation prohibiting dual citizenship and conclude international treaties and agreements thereon;

8. ensure that the citizens of Mongolia and foreign residents are prohibited from violating the Fights and freedoms of others or cause damage to others while exercising their own rights and freedoms, as well as to infringe upon the security and the vital national interests of the country.

\section{Y. ECONOMIC SECURITY}

32. Economic security means building an economic structure which has the potential for effective economic reproduction through the use of internal resources, for meeting the basic needs of the people and strengthening the country's independence, and in cases of need to sustain the country for a definite period of time.

Economic security represents the cornerstone of the independence and sovereignty of Mongolia.

33. External factors which may adversely affect the ensuring of economic security:

1. Restricting or impeding the development of foreign trade and economic cooperation;

2. Turning into a raw materials appendage to other countries;

3. Plummeting of prices of the country's export items of strategic importance and/or loss of markets for them;

4. Direct dependence on any one country in economic branches of strategic importance.

34. Internal factors which may adversely affect economic security:

1. Failure of the ecological policy leading to the depletion of water and forest resources, reduction of agricultural lands;

2. Widening of disparity in regional development leading to economic imbalances; 
3. Depletion of the gene pool of Mongolian domestic farm animals and acclimated verities of grains;

4. Failure of customs policy leading to penetration of items which may adversely affect the security of Mongolia and its population, to the reduction of sources of budget revenues which may have a negative impact on national production;

5. Increase of the State's current budget deficit, failure of the State policy to protect the national currency, the togrog;

6. A sharp rise in inflation resulting in the fall of the togrog's exchange rate, and an increase in the number of families with incomes below the minimum level of subsistence;

7. Growth of the debt to other countries or international organizations and thus increasing the vulnerability to external pressures and dependence;

8. Sharp increase in the number of foreigners and stateless persons resident in Mongolia, and mass emigration of national trained personnel and skilled workers;

9. Sharp increase in the share in the overall population of the unemployed, including the number of persons of working age with disabilities.

35. Ways and means to ensure economic security: Mongolia shall:

One. 1. Pursue a uniform government policy in the follow-ing fields:

- economic structural changes

- foreign economic relations

- issues related to indebtedness and debt servicing

- budget policy

- monetary policy

- scientific and technological policy

- Economic reporting, accounting and information

Two. 1 .recognize the following branches as having strategic importance due to their role in ensuring economic security:

a. in the spheres of production:

- food and agriculture

- mining

- light industry

- chemical industry

$b$. in the sphere of infrastructure:

- Energy

- Fuel 
- telecommunications and information

- roads and transport

2. Encourage foreign investments in the following areas:

- developing strategically important branches

- increasing the production of export items and foodstuffs

- Internally processing raw materials, producing mechanical components and spare parts thus substituting imports.

Three. Pursue the following guidelines implementation of the national policy on ensuring economic security:

1. develop economic and social infrastructures;

2. set up economic zones capable of providing conditions for the relatively independent and integrated development of local areas;

3. develop industries producing ecologically clean prod-ucts, and introduce waste less technologies;

4. determine, secure and replenish annually reserves of essential food and consumer goods; produce domestically certain types of goods of strategic importance;

5. maintain the country's hard currency reserves at an amount equal to the total import costs of not less than two months;

6. protect the gene pool of Mongolian farm animals as well as the acclimated varieties of grains;

7. when developing trade and economic relations with various countries, safeguard against situations where the country's economy, especially its branches of strategic importance, may become the object of dominance by one country or a group of countries or where the country may turn into a raw materials appendage. Impart an interest in influential and developed countries to freely maintain and expand relations with this country;

8. ensure the right of Mongolia to have access to the sea on the basis of international legal norms;

9. with a view to ensuring economic security, expand bilateral and multilateral equitable, mutually beneficial trade and economic cooperation with neighboring countries, and the developed countries of the West and East; secure the country's appropriate place in the regional trade and economic network;

10. Keep the amount of strategically important raw materials and equipment to be imported, as well as the number of experts and workers to be received from any one country at the level not capable of affecting national security;

11. Avoid situations where incentives and concessions ac-corded to for- 
eign investors to protect their economic interests surpass the concessions and economic allowances provided to the national investors and producers; oversee compliance there-with;

12 when receiving loans from foreign countries and inter-national organizations, care should be taken so that their total does not exceed the country's capacity to pay back within a speci-fied time period;

13. settle the issues of repayment of loans made prior to 1990 and their interests in accordance with international practices taking into consideration the interests both of this country and the creditor States as well as causes that led to such debts;

14. When promoting the policy of increasing the share of exports in foreign trade, care should be taken to market processed and finished goods.

\section{SCIENTIFIC AND TECHNOLOGICAL SECURITY}

36. Scientific and technological security means the insurance of conditions for the use of technologies, information and research for the purpose of the country's development adapted to its ecological conditions, for enhancing the national scientific potential and intellectual competitiveness.

37. External factors which may adversely affect the ensuring of scientific and technological security:

1. Technological dependence on a country in an economic branch having strategic importance for the development of the country;

2. Backwardness in scientific and technological development

38. Internal factors which may adversely affect the ensuring of scientific and technological security:

1. Lack of a uniform government policy for scientific and technological development;

2. Loss of Mongolian traditional time-tested technologies;

3. Insufficient government protection of specific Mongolian technologies as well as studies of and information on the gene pool of the population, plants and animals, and loss of scientific and technological secrets;

4. Failure to introduce world advanced technologies due to the absence of favorable economic and legal conditions and guarantees;

5. Loss of competitiveness of national techniques and tech-nologies due to non-introduction of modern achievements of science and technology, and resultant retardation therein;

6. Inability to make full use of the national intellectual potential and of trained personnel in the country; 
7. Lack of conditions for the utilization of new and innovative technologies in production.

39. Ways and means to ensure scientific and technological security:

Mongolia shall:

1. define a uniform scientific and technological policy and its priority tasks, allocate not less than three percent of the national income to financing scientific activities;

2. encourage research, secure scientific discoveries and intellectual products, create legal guarantees for introduction of foreign technologies adapted to Mongolian conditions;

3. Develop and introduce technologies suitable for Mongolian conditions for the exploitation of natural resources, food and agricultural raw materials;

4. set up an integrated national scientific and technological information network and database and place them under government protection;

5. Encourage fair competition for the introduction of scientific and technological achievements in industry, and the devel-opment of industrial technologies. Apply the principle of providing tax allowances and soft loans on priority basis to private enterprises and institutions which gain achievements in the devel-opment of scientific and technological solutions of national importance and in using their results in production and practical work;

6. Strengthen the competitiveness of science and technology, its capability to develop through increasing involvement of the private sector in scientific and technological development;

7. create a technological infrastructure and favorable en-vironment, introduce a system of proper assessment of the content, potentiality and status of national technology;

8. concentrate the intellectual potential of science and technology, and the available funds and resources primarily in the implementation of nationally important research projects;

9. improve steadily the quality of the educational system, and encourage and develop people's talents;

10. promote special-purpose training of highly skilled specialists in particularly needed technological fields, create intel-lectual and material prerequisites and conditions for national sci-entists to work and prosper in their own country;

11. introduce the practice of selecting promising children from the second- 
ary school level for subsequent work in scientific and technological research fields as well as in processing and manufacturing industries, of providing them with facilities and conditions for individualized education and apprenticeship training;

12. Ensure priority development of artificial intelligence management technology and biotechnology. While paying special attention to acquiring the technologies of assembling computers and other electronic equipment, the use of solar and wind energy, as well as to the establishment of an integrated telecommunication network based on modern technology, expand work in the development of research-intensive new materials;

13. develop international scientific and technological cooperation and secure the country's place in international and regional integration;

14. Preserve national scientific and technological traditions and methodologies, adapt them to modern conditions.

\section{YII. INFORMATION SECURITY}

40. Information security means the situation where conditions are ensured for the Government to assess objectively the country's actual internal and external situation and make correct decisions, for government organs and the people to have the necessary information for the exercise of their powers and rights provided for by the Constitution and for the dissemination abroad of information about Mongolia.

Freedom of information constitutes an important means for the development and strengthening of democracy.

41. External factors which may adversely affect the insurance of information security:

1. Dissemination of false information by outside sources that may sow doubts about Mongolia's independence and territorial integrity in other countries, lead to interference in its internal affairs by any State or sow distrust between ethnic groups in Mongolia, and lead to disputes and conflicts as well as to internal instability;

2. Dependence upon one country or a group of countries in the field of information.

42. Internal factors which may adversely affect the insurance of information security:

1. Use of the mass media by any force as an instrument to increase tension in the country, settle a personal score or damage others' reputation; 
2. Curtailment of the right to seek, receive and impart in formation;

3. Disclosure of state secrets related to ensuring national security and defense as well as public law and order;

4. Curtailment of the rights of citizens and institutions calumniated in the mass media to protect themselves through the mass media or courts of justice;

5. Causing damage to others by supplying incomplete or false information;

6. Failure to keep abreast of the course of events or of scientific and technological developments as a result of the breach of information freedom or lack of access to information.

43. Ways and means to ensure information security: Mongolia shall:

1. have a multi-source information database on external and domestic situations;

2. safeguard mass media agencies and means against becoming subservient to foreign organizations or citizens;

3. create the legal basis for the dissemination of true and objective news and information by the mass media;

4. establish a national structure and legal safeguards for the protection of computerized information;

5. join international information networks and carry out efficient dissemination of true and objective information on Mon-golia;

6. have the mass media serve the cause of developing and strengthening democracy and pluralism, and disallow deliberate distortion and abuses of truth and objective reality;

7. guard against information intrusion detrimental to Mon-golia's independence, culture and way of life, customs and traditions;

8. Have the mass media and other information sources create an information environment conducive to national security through the dissemination of authentic information and commu-nications on security matters.

\section{YIII. SECURITY OF MONGOLIAN CULTURE AND WAY OF LIFE}

44. The security of Mongolian culture and way of life means the situation where conditions are ensured for the preservation of the national language, history, culture, customs and traditions that constitute the basis for the existence and development of the Mongolian nation and its statehood, and conditions for the eternal existence of the Mongolian people.

45. External factors which may adversely affect the security of Mongolian culture and way of life: 
1. Emergence of conditions where the blurring of the distinctive features of Mongolian culture and way of life may lead to its eventual assimilation into others as a result of political, economic and socio-cultural policies of foreign countries and ex-ternal forces;

2. Indoctrination of inhumane ideologies such as chauvinism, racism, fascism, and reactionary religious teachings, uncontrolled dissemination of materials inciting violence, murder, and pornography.

46. Internal factors which may adversely affect the Insurance of the security of Mongolian culture and way of life:

1. Disregard for Ana belittling of the cultures of other peo-ples and exaggeration of the values of the historical traditions of Mongolian culture and way of life, which may ultimately lead to the country's self-isolation as a nation;

2. overestimation and blind imitation of civilizations of other nations or failure to safeguard against the negative side-effects of a market economy and modern science and technology;

3. Emergence of an intellectual vacuum in society due to external and internal situations, and lapsing of society into intellectual degradation;

4. Smuggling of objects of historical and artistic value abroad.

47. Ways and means of ensuring the security of Mongolian civilization:

Mongolia shall:

1. formulate and pursue an active policy for reinforcing and enriching the basic characteristics of the nomadic civilization; preserve all valuable and progressive elements of Mongolian culture and traditions in economy, statehood, material and intellectual life, and develop them in a harmonious combination with the values of world civilization;

2. perfect the Mongolian language in line with the extant trends by mastering both the traditional and Cyrillic scripts;

3. Create an educational system in accordance with the traditions of the Mongolian Enlightenment and present-day world. Standards; protect and enhance the national intellectual poten-tial;

4. create conditions for learning about and perceiving the history, culture and mentality of the people as well as the nature of the homeland; inculcate in every citizen, particularly the younger generation, a strong sense of patriotism and an aspiration to cherish the country's name; make the study, instruction and popularization of Mongolian history, religion and culture the special ob-ject of the governments constant care and support;

5. pursue a policy of encouraging the search, protection, recovery and restoration of the relics of Mongolian culture, prevent the illegal outflow of 
historical and cultural treasures;

6. carefully preserve and rely on the intrinsic ability of the Mongols to live in harmony with Nature, their traditional abiding respect for statehood, knowledge and talent displayed in thought and in deed, and their keen sense of community;

7. restore and preserve specific types of the traditional economic Mongolian know-how and technology and the heritage of national culture and craftsmanship, and protect their work and masterpieces;

8. respect freedom of conscience and religious belief, refrain from interfering in the affairs of the church on the part of the state; make possible for the church to freely conduct its services; keep under state supervision the number of places of worship, their locations and the actual number of the clergy;

9. keep inter-confessional relations under particular care of the state and forestall crises and conflicts; keep the activities of any church within the legal framework, forestalling any damage to national culture as well as customs and traditions;

10. expand relations and ties with Mongols living in other countries, help them maintain and develop Mongolian culture and traditions; Mongolia being the ancestral homeland of the Mon-gols, and while pursuing the policy of encouraging the desire of Mongols living abroad to see Mongolia develop, shall particularly eschew the injection of any political intent in these relations;

11. Prevent the spread of such man-hating ideologies as racism and fascism, which may undermine the national unity of the Mongolian people, the public morals and spirit; the publication, display and dissemination of productions advocating violence, murder, war and pornography shall be permitted exclusively within the legal framework under special regulations.

\section{SECURITY OF THE POPULATION AND ITS GENE POOL}

48. The security of the population and its gene pool implies a situation where conditions are ensured for the maintenance and protection of the health and gene pool of the Mongolian population and its sustained growth.

49. External factors which may adversely affect the insurance of the security of the Mongolian population's gene pool:

1. transgression of radioactive substances, chemical pollution, acid rains and epidemics through atmosphere, water and soil;

2. joining the international division of labor as a country engaged in production harmful to the ecology and the populations"health, 
3. Influx of foodstuffs, chemicals and consumer goods adversely affecting the health of the population and its gene pool due to erroneous foreign trade policy and slackened control over the quality of imported goods.

50. Internal factors which may adversely affect the insurance of the security of the population and its gene pool:

1. Outbreak of acute human and animal diseases;

2.damage of the gene pool as a result of inbreeding; an increase in the number of mentally deficient and intellectually retarded persons exceeding the admissible ratio to that of normal people and thus exceeding the world average indicator;

3. spread of alcoholic addiction affecting the overall health of the population and its gene pool;

4. imbalance in the age and sex structure of the population;

5. spread of famine and dystrophy among the population; shortage of drinking water or its pollution;

6. Breach of sanitary and other established hygienic standards by domestic producers; production and uncontrolled distribution of foodstuffs, consumer goods and other products harmful to the health of the population;

7. Breach of safety rules of handling chemicals resulting in the negative impact on the health and gene pool of the population.

51. Ways and means of ensuring the security of the population and its gene pool:

Mongolia shall:

1. Formulate and pursue a comprehensive Government policy aimed at ensuring the gene pool, health and sustained growth of the Mongolian population; revive, on public initiative, the tradition of keeping track and being aware of the family genealogy up to 7-9 generations of one's ancestors;

2. make prophylaxis the basis of Government policy and activities in health protection;

3. consider as a priority task the prevention of inbreeding, alcoholism and drug addiction which would negatively affect the Mongol gene pool and comprehensive study of Mongols as human beings and of the Mongolian population; promote the policy of early diagnosis of and preventive measures against mental diseases and insurance of psychological security of the population;

4. establish a monitoring system for safeguarding against radioactive and chemical pollution, bacteriological contamination, as well as diseases and epidemics originated there from in the contiguous areas of neighboring coun- 
tries;

5. prohibit the importation into or transit through the territory of Mongolia of particularly poisonous chemical and biologi-cal substances having direct and residual effect on human genes and the health of the population as well as proscribe economic activities connected with storage or processing of hazardous wastes of foreign countries;

6. institute regular control over the incidence and frequency cycles of genetic diseases, anomalies and mental deficiencies;

7. exercise constant control over the accumulation in the environment of chemicals harmful to human genes;

8. keep food security under special Government care, exercise control over the quality of foodstuffs to safeguard against the possible presence of toxic substances hazardous to human health and genetic system, set up a national laboratory;

9. pursue the policy of closely monitoring the social, illogical and environmental factors which may adversely affect the health of the population, as well as developing pharmaceutical and biopreparation technologies so as to domestically produce at least fifty percent of the essential drugs needed, and ensure a priority use of domestic raw materials of mineral, plant and animal extraction in pharmaceutics;

10. Attain world average indices of population health, reduction of maternal and infant morbidity and mortality rates; promote the policy appropriate management of birth rate in order to achieve a sound solution to certain pressing problems of child and maternal health.

\section{ECOLOGICAL SECURITY}

52. Ecological security means the situation where conditions are ensured for the prevention of a negative impact on hu-man environment and the economy as a result of ecological and climatic changes, and of irrational use and insufficient protection of natural resources.

53. External factors which may adversely affect the insurance of ecological security:

1. Intensification of desertification, changes in the level and distribution of precipitation and increased frequency of droughts and blizzards as a result of global climatic transformations; thin-ning of the ozone layer;

2. increase in the levels of radiation, chemical pollution and acid rain transgressing the borders by atmospheric and water currents; outbreak of hu- 
man and animal epidemics; inroads of rodents and insects harmful to forests, pastures and vegetation;

3. Turning into a supply base of raw materials for the pro-duction of hallucinogens or psychotropic and other substances harmful to human intellect and health.

54. Internal factors which may adversely affect the insurance of ecological security:

1. Destabilization of ecological balance, increase of soil erosion and destruction, depletion of the gene pools of plants and animals;

2. Depletion of the vegetation and forests, drying up of rivers and lakes, draining of subterranean waters and parching of pas-tures;

3. Exploitation of natural resources in a skimming and waste-ful manner;

4. Accumulation of wasteful techniques; increase of industries producing hazardous wastes; turning into a dumping ground for toxic wastes of foreign countries.

55 Ways and means to ensure ecological security: Mongolia shall:

1. make the concern of Government policy the activity designed to revive the national traditions of caring for and protect-ing Nature, and to impact them to the entire society;

2. apply the principles of meeting the basic human needs within the limits of renewable natural resources, and using nonrenewable or gradually renewable resources for the country's development as additional factors;

3. Develop the economy with ecological orientation and promote the policy of securing an appropriate position in the world market with its ECOMARK products;

4. protect certain parts of the country's territory, turning them into national reserves while gradually drawing the rest of the territory into economic circulation in line with policies and mechanisms designed to maintain ecological balance;

5. avoid turning land into ownerless wastes in the name of free ownership, fragmenting it into pieces for the alleged purpose of giving shares to everyone, and the irreversible exhaustion of pastures;

6. pursue a course aimed at establishing eco-economic zones to develop complexes comprising suitable combinations of economic infrastructure and natural resources capable of ensuring ecological balance, while avoiding further fragmentation of the present administrative and territorial divisions;

7. In planning and building towns and settlements avoid overcrowding 
the population which may become the cause of ecological disturbances of any given region;

8. implement the policy designed to restrict the use as fuel of shrubs which are effective in blocking sand movements and retaining soil moisture; make use of the possibilities of neighboring States in meeting the country's needs in lumber; pursue as a national strategic goal the complex of measures aimed at carrying out reforestation, prevention of fires, protecting the sources of springs and rivers as well as crop fields by green belts;

9. plant greenery in degrading areas, expand year by year the areas under vegetation;

10. Constantly update the national Red Data Book; promote a systematic policy for protection of the gene pools of endangered species in the world and in Mongolia;

11. organize the commercial use of valuable herbs, edible and technical plants through their acclimation and planting; restrict the export for economic reasons of economically valuable finds of animal and plant extractions native to Mongolia;

12. make lakes, rivers, water pools and all other water resources of Mongolia the object of special protection by the government and the people, establish a system of managing and monitoring the rational use of water resources, water preservation, building reservoirs for collecting rain and snow drainage, and ex-ercise control over the quality and reserves of clean water for drinking and industrial usage;

13. conduct through effective means and methods sustained activities against the testing and emplacement of nuclear weapons in the territory of Mongolia and in areas adjacent to its borders;

14. apply the principle of restricting economic activities harmful to the environment through legal and economic means;

15. cease production activities which emit gases damaging the ozone layer, and impose restrictions on such products;

16. establish a system of prevention and combating natural calamities, and other unforeseen disasters;

17. conduct researches on traditional measures of survival that enable the population to live in arid and desert regions; and develop the national capacity and preparedness to survive any possible climatic changes;

18. while fully incorporating the habitats of unique wildlife and vegetation as well as the intersections of biospheres in Mongolia in the national reserve 
areas, take measures to secure international status for some of them by including them in the register of world heritage of civilization;

19. promote the policy of having the territory of Mongolia included in the internationally protected ecological zones;

20. Acquire advanced technology and know-how by concluding or becoming party to international treaties and agreements concerning environmental protection and rehabilitation, by realizing ecological projects in cooperation with international organizations and donor countries; and set up a sister of environmental disaster prevention designed to enable the country to survive possible disasters with the least possible dam-age under any conditions.

\section{OTHER PROVISION'S}

56. The State Great Hural shall make appropriate changes and amendments with regard to the basic structure and content of the Concept of National Security of Mongolia on the proposal of the National Security Council, taking into account the changes and trends in the global, regional and domestic situations and the development of events. 